Jurnal Ekonomi dan

Manajemen

Teknologi (EMT)

\title{
Pengukuran Tingkat Kapabilitas Tata Kelola Teknologi Informasi Menggunakan Framework Cobit 5 dan Rekomendasi Perbaikan (Studi Kasus: Badan Pengembangan Teknologi Informasi)
}

\author{
Rizky Sugiharti Utami ${ }^{1 *}$ \\ ${ }^{1}$ Prodi Sistem Informasi Bisnis, Fakultas Magister Manajemen Sistem Informasi, \\ Program Pascasarjana Universitas Gunadarma, Depok, Indonesia.
}

\begin{abstract}
Abstrak. Pada penelitian ini bertujuan untuk mengukur tingkat kapabilitas tata Kelola TI serta memberikan rekomendasi untuk perbaikan Tata Kelola TI di Badan Pengembangan Teknologi Informasi (BPTI) menggunakan COBIT 5. Domain yang dipilih pada penelitan ini adalah APO dan BAI dalam rangka meningkatkan pelayanan TI dan mengoptimalkan penerapan TI pada lingkungan BPTI. Metode penelitian yang digunakan adalah metode wawancara dan kuesioner dalam mendapatkan data penelitian. Berdasarkan basil penelitian didapatkan babwa pengukuran terbadap delapan proses yang dipilih menunjuk.kan bahwa sebagian besar dari proses sudah berada pada level 1, dan sebagian kecil berada di level 0. Berdasarkan hasil penentuan prioritas, proses yang menjadi prioritas utama dalam melakukan perbaikan adalah APO07 yaitu Mengelola Sumber Daya Manusia. Penelitian ini hanya dilakukan pada delapan proses dimana sesuai dengan yang sudah dipetakan sebelumnya, agar penelitian ini lebih lengkap dan komprehensif, dapat dilakukan dengan menggunakan proses area pada COBIT 5 lainnya.
\end{abstract}

Kata kunci: Capability Level; COBIT 5; IT Governance.

\begin{abstract}
This study aims to measure the level of IT Governance capability and provide recommendations for improving IT Governance in Information Technology Development Institute using COBIT 5. The domains chosen in this research are APO and BAI in order to improve IT services and optimize IT implementation in BPTI environment. The research method used are interviews and questionnaires in obtaining research data. Based on the results of the study, it was found that the measurement of the eight selected processes indicated that most of the processes were already at level 1 , and a few were at level 0 . Based on the results of prioritization, the process that became the top priority in making improvements was APO07, namely Managing Human Resources. This research was only carried out in eight processes which were in accordance with previously mapped, so that this research was more complete and comprehensive, it could be carried out using other process areas in COBIT 5.
\end{abstract}

Keywords: Capability Level; COBIT 5; IT Governance. 


\section{Pendahuluan}

Keberhasilan penggunaan teknologi informasi yang banyak dilakukan oleh perusahaan dalam mendukung seluruh proses bisnis kini menginspirasi para pemimpin/pimpinan perguruan tinggi untuk menerapkan proses teknologi informasi yang efektif dan efisien dengan meningkatkan kemampuan yang kompetitif, dan mentrasformasikan proses kerja, layanan, dan hubungan antar civitas akademik, peneliti dan dari berbagai level lainnya. Karena itulah penerapan teknologi informasi perlu direncanakan dan disusun dengan baik melalui tata kelola (IT Governance).

\section{Control Objective for Information and Related} Technology (COBIT) adalah sebuah kerangka kerja atau best practice manajemen dan teknologi informasi untuk menjembatani kesenjangan antara masalah-masalah teknis IT, kebutuhan control, dan resiko bisnis. COBIT menyediakan kerangka kerja untuk mengatur keselarasan TI dengan bisnis. Versi COBIT yang terbaru adalah COBIT 5 dimana keunggulannya adalah dapat mengidentifikasi beberapa tantangan yang dihadapi COBIT Maturity Model dan menawarkan model penelitian alternatif.

Badan Pengembangan Teknologi Informasi merupakan unit yang bertugas untuk memberikan layanan support system kepada institusi baik untuk kegiatan akademik, keuangan maupun layanan umum dari sisi Teknologi Informasi, selain itu bertugas pula untuk melakukan kajian untuk pengembangan teknologi informasi. Berdasarkan hasil observasi awal bahwa Badan Pengembangan Teknologi Informasi ini memiliki kendala dalam melakukan Layanan Teknologi Informasi di Institusi. Layanan TI ini sangat vital keberadaannya untuk institusi karena dari situ dibutuhkan informasi yang cepat, tepat dan $u p$ to-date serta berkelanjutan sesuai dengan bisnis yang sedang dijalankan oleh institusi. Namun dalam melakukan pelayanan TI BPTI masih kurang optimal, dampak yang ditimbulkan kan berakibat tidak baik bagi institusi. Permasalahan-permasalahan terkait perencanaan dan operasional merupakan indikasi adanya masalah dalam tata Kelola TI. Dengan adanya penelitian ini Badan Pengembangan Teknologi Informasi mengharapkan dapat mengukur tingkat kapabilitas tata Kelola TI serta mendapatkan rekomendasi aktivitas perbaikan tata kelola TI. Kerangka kerja yang digunakan dalam penelitian ini adalah COBIT 5 sebagai alat bantu untuk pengukuran tingkat kapabilitas Layanan TI Badan Pengembangan Teknologi Informasi serta merancang rekomendasi aktifitas perbaikan tata Kelola TI di BPTI menggunakan COBIT.

\section{Literature Review}

\section{Tata Kelola Teknologi Informasi}

"Specifying the decision rights and accountability framework to encourage desirable bebaviour in the use of IT" (Weill \& Ross, 2004). Weill \& Ross mendefenisikan tata kelola teknologi informasi sebagai menentukan keputusan spesifik dan kerangka kerja organisasi yang akuntabel untuk mengarahkan perilaku yang diinginkan dalam penggunaan teknologi informasi dengan menegaskan pada siapa yang secara sistematis membuat dan berkontribusi pada keputusan tersebut.

Tujuan tata kelola TI yaitu untuk memahami masalah dan kepentingan strategis teknologi informasi, sehingga perusahaan dapat mempertahankan bisnisnya dan menerapkan strategi untuk perusahaan bersaing lebih baik di masa sekarang dan di masa depan. Oleh karena itu, tata kelola teknologi informasi bertujuan ingin memastikan bahwa harapan untuk TI terpenuhi serta risiko TI dikurangi.

Definisi tata kelola diatas merupakan definisi tata Kelola teknologi informasi dan pentingnya tata kelola teknologi informasi bagi sebuah organisasi. Dengan adanya Tata Kelola Teknologi Informasi yang berjalan di dalam suatu organisasi, maka seluruh IT Process dapat berjalan dengan sistematis, terkendali serta efektif. Outcome dari Tata Kelola IT yang baik tersebut dapat dicapai apabila tata Kelola TI tersebut dikembangkan dengan menggunakan IT Framework berstandar internasional seperti ISO IT Security, COBIT, COSO, serta IT-IL Management.

\section{COBIT 5}

COBIT 5 merupakan panduan atau kerangka kerja yang komprehensif yang berfungsi membantu sebuah organisasi dalam mencapai 
tujuannya terkait dengan tata Kelola TI dan manajemen teknologi informasi. Fungsi COBIT 5 lainnya juga membantu suatu organisasi dalam menciptakan $V$ alue dari suatu teknologi informasi. COBIT 5 bersifat umum dan dapat digunakan pada segala jenis organisasi dan tidak bergantung pada ukuran suatu organisasi (ISACA, 2012).

COBIT 5 menyediakan berbagai macam proses yang sudah dilengkapi dengan panduan untuk masing-masing prosesnya. Area Governance memiliki domain Evaluate, Direct, Monitor (EDM) yang memiliki 5 proses didalamnya yaitu : Ensure Governance framework setting \& maintenance (EDM01), Ensure benefits delivery (EDM02), Ensure risk optimization (EDM03), Ensure resource optimization (EDM04), Ensure stakeholders transparency (EDM05). Area Management dikelompokkan kedalam 4 domain dimana didalamnya mencakup 32 proses. Keempat domain tersebut adalah:

a. Align, Plan, Organize (APO) yang terdiri dari 13 proses

b. Build, Acquire, and Implement (BAI) yang terdiri dari 10 proses

c. Deliver, Service, and Support (DSS) yang terdiri dari 6 proses

d. Monitor, Evaluate and Assess (MEA) yang terdiri dari 3 proses.

Keseluruhan prosesnya dapat dilihat pada gambar berikut dimana terdapat 37 proses dalam domain Governance dan management.

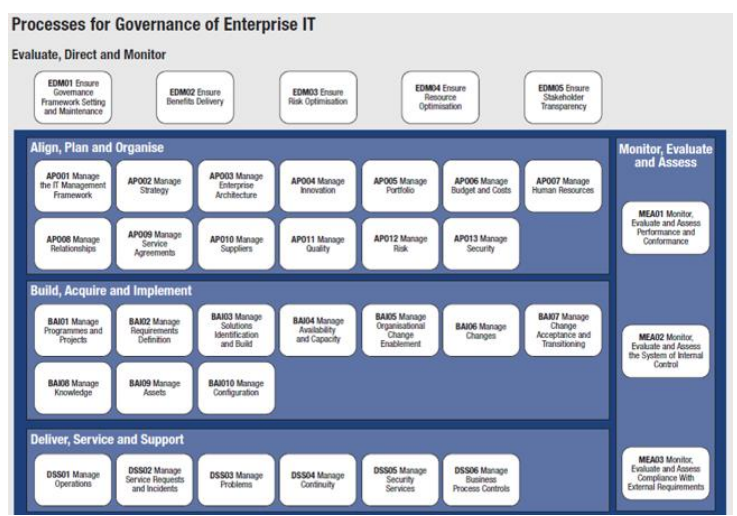

Gambar 1. Processes for Management of Enterprise IT

Dimensi kapabilitas memiliki tingkatan (level) kapabilitas dimana pada masing-masing tingkatan memiliki karakteristik untuk pengukurannya dari proses. Kapabilitas proses memiliki 6 tingkatan dari skala 0 sampai dengan 5, yaitu:

1. Level 0 - Incomplete Process. Dimana proses tidak diimplementasikan atau gagal mencapai tujuan dari proses itu sendiri. Pada level ini tidak terdapat banyak bukti atau bahkan tidak ada bukti sama sekali yang terdapat menunjukkan pencapaian sistematis dari tujuan sebuah proses

2. Level 1 - Performed Process. Proses ini dikerjakan secara adhoe dan tidak terorganisasi oleh karenanya sangat tergantung pada kemampuan individual. Namun proses yang diimplementasikan tersebut pada intinya dapat mencapai tujuan.

3. Level 2 - Managed Process. Proses yang dikerjakan telah direncanakan, dimonitor, didokumentasikan dan disesuaikan agar dapat memenuhi objektifitas yang telah diidentifikasi sebelumnya. Produk yang dihasilkan dari proses tepat sasaran, terkontrol dan terpelihara.

4. Level 3 - Established Process. Proses yang diimplementasikan sebelumnya dilaksanakan berdasarkan standar dari suatu proses, diimplementasikan sebagai proses yang terdefinisi yang mampu mencapai outcome dari proses tersebut. Proses didokumentasikan dan dikomunikasikan dalam rangka efisiensi organisasi. Standar suatu proses dibuat dan dikembangkan secara efektif bersama dengan kebutuhan infrastruktur

5. Level 4 - Predictable Process. Proses yang diimplementasikan sebelumnya, sekarang diimplementasikan dengan menggunakan batasan yang terdefinisi untuk mencapai output dari proses tersebut. Pada level 4 proses dimonitor dan diukur serta diprediksi.

6. Level 5 - Optimising Process. Proses sudah dikembangkan secara berkelanjutan untuk mencapai tujuan organisasi.

\section{Metodologi Penelitian}

Berikut merupakan penjelasan dari tahapan penelitian:

1. Merumuskan Masalah: Pada tahap ini akan ditentukan tujuan atau sasaran penelitian dari 
permasalahan yang ada pada Badan Pengembangan Teknologi Informasi

2. Studi Literatur: Pada tahap ini dilakukan studi literatur guna mencari referensi terkait masalah yang terjadi pada BPTI.

3. Pengumpulan Data: Untuk mengumpulkan data dilakukan 2 metode yaitu wawancara dan kuesioner.

4. Pemetaan Masalah Dengan COBIT 5: Pemetaan masalah dilakukan berdasarkan masalah yang muncul pada institusi dari hasil wawancara yang dipetakan antara 37 domain COBIT 5.

5. Melakukan Pengukuran Kapabilitas: dilakukan pengukuran pengukuran tingkat kapabilitas dari hasil pengisian kuesioner

6. Penentuan Target Kapabilitas: penentuan target ini dilakukan berdasarkasn hasil wawancara dengan kepala BPTI yakni apa yang diharapkan dari kepala BPTI dan kesimpulannya.

7. Penentuan GAP Value dan Prioritas Tingkat Kapabilitas: Penentuan GAP Value dan prioritas dilakukan berdasarkan hasil penentuan target dan juga kuesioner untuk prioritas yang dilihat dari segi dampak yang diberikan, kemudahan dalam implementasi dan kesiapan organisasi dan teknologi.

8. Pembuatan Rekomendasi: pembuatan rekomendasi diberikan berdasarkan Framework COBIT 5.

\section{Hasil dan Pembahasan}

\section{Pemetaan Masalah kedalam Proses COBIT}

5.

Berdasarkan permasalahan yang ada dan telah diidentifikasi sebelumnya kemudian dipetakan dengan proses proses yang ada pada COBIT 5 yang relevan beserta dengan permasalahan yang ada. Pendekatan proses dilihat dari kesesuaian permasalahan yang ada dengan deskripsi dan tujuan bisnis dari setiap proses-proses yang ada dalam COBIT 5. Berdasarkan hasil wawancara didapatkan hasil pemetaan masalah kedalam proses COBIT 5 yaitu 8 proses (APO07, BAI01, BAI02, BAI03, BAI04, BAI06, BAI09, BAI010) dan tingkat kapabilitasnya akan diukur, yang nantinya hasilnya akan dijadikan dalam memberikan rekomendasi perbaikan prosesproses terpilih dan solusi pada permasalahan yang terjadi di BPTI. Dalam melakukan pengukuran tingkat kapabilitas dilakukan dengan menyebarkan kuisioner yang mengacu pada Process Assesment Model (PAM) COBIT 5 kepada para staff Badan Pengembangan Teknologi Informasi (BPTI).

\section{Pengukuran Tingkat Kapabilitas}

Hasil pengukuran tingkat kapabilitas dapat dilihat yaitu:

Tabel 1. Hasil Pengukuran Tingkat Kapabilitas

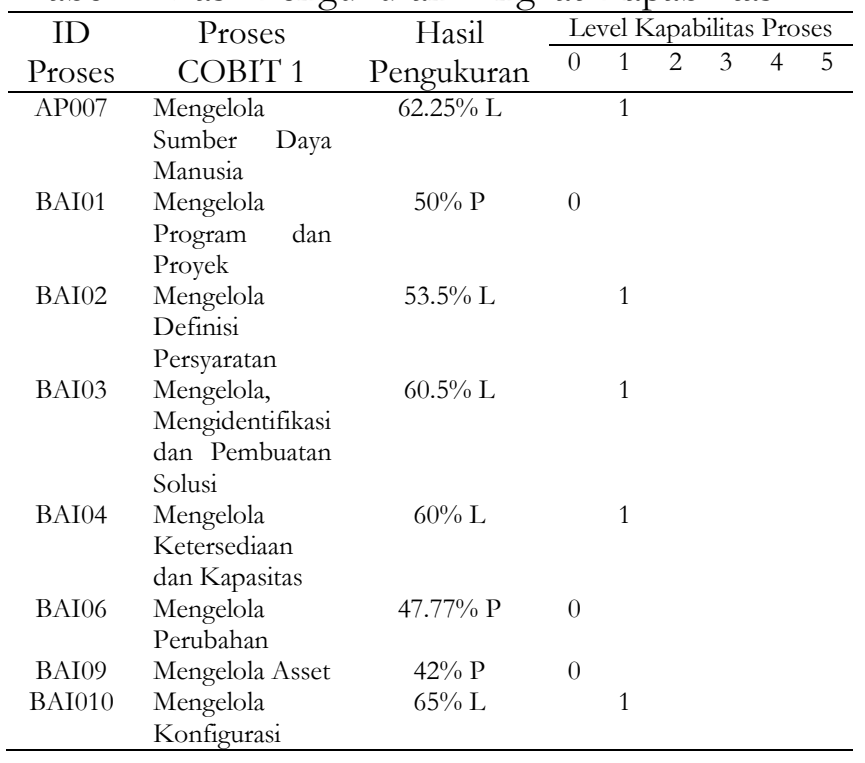

Data hasil dari pengukuran diatas menunjukkan bahwa tingkat kapabilitas proses tata kelola TI saat ini dari proses COBIT 5 yang terpilih masih rendah dengan rata-rata proses masih berada di level kapabilitas 1. Tingkat kapabilitas level 0 dengan 3 proses dan Tingkat kapabilitas proses level 1 dengan 5 proses.

\section{Analisis Kesenjangan (GAP Value)}

Analisis kesenjangan ini dilakukan untuk mengetahui kesenjangan yang ada ataupun perbedaan yang terjadi saat ini dengan kondisi yang diinginkan serta upaya yang harus dilakukan untuk meminimasi kesenjangan tersebut. Analisis kesenjangan pada tingkat kapabilitas tata kelola TI di Badan Pengembangan Teknologi Informasi (BPTI) dilihat berdasarkan hasil wawancara. Berdasarkan wawancara dengan Kepala Badan Pengembangan Teknologi Informasi didapatkan informasi bahwa target yang diinginkan terhadap masing-masing proses berbeda-beda. Hal ini disesuaikan dengan keadaan dan kemampuan BPTI saat ini untuk mencapai target kedepannya, yang diharapkan dapat membuat BPTI menjadi lebih baik dan 
Tabel 3. Hasil Perhitungan

\begin{tabular}{|c|c|c|c|c|c|c|c|c|c|c|}
\hline \multirow{5}{*}{$\begin{array}{c}\text { ID } \\
\text { Proses }\end{array}$} & \multirow{5}{*}{ Proses COBIT } & \multicolumn{8}{|c|}{ Kriteria } & \multirow{5}{*}{$\begin{array}{c}\text { Jumlah } \\
\text { Total }\end{array}$} \\
\hline & & \multirow{2}{*}{\multicolumn{2}{|c|}{ Dampak }} & \multirow{2}{*}{\multicolumn{2}{|c|}{$\begin{array}{l}\text { Kemudahan } \\
\text { Implementasi }\end{array}$}} & \multicolumn{4}{|c|}{$\begin{array}{c}\text { Kemudahan dan Kesiapan } \\
\text { Organisasi }\end{array}$} & \\
\hline & & & & & & \multirow{2}{*}{\multicolumn{2}{|c|}{$\begin{array}{ll}\text { SDM } \\
\mathrm{X} 3 \\
\end{array}$}} & \multirow{2}{*}{\multicolumn{2}{|c|}{$\begin{array}{c}\text { Teknologi } \\
\mathrm{X} 3 \\
\end{array}$}} & \\
\hline & & $\mathrm{X} 1$ & $\mathrm{X} 1$ & & & & & & & \\
\hline & & Y1 & Z1 & Y2 & $\mathrm{Z} 2$ & Y3 & Z3 & Y4 & $\mathrm{Z} 4$ & \\
\hline $\mathrm{APO} 07$ & $\begin{array}{c}\text { Mengelola } \\
\text { Sumber Daya } \\
\text { Manusia }\end{array}$ & 9 & 27 & 3 & 15 & 3 & 6 & 3 & 6 & 54 \\
\hline BAI01 & $\begin{array}{c}\text { Mengelola } \\
\text { Program dan } \\
\text { Proyek }\end{array}$ & 5 & 15 & 5 & 5 & 1 & 2 & 1 & 2 & 24 \\
\hline BAI02 & $\begin{array}{c}\text { Mengelola } \\
\text { Definisi } \\
\text { Persyaratan }\end{array}$ & 5 & 15 & 1 & 9 & 1 & 2 & 3 & 6 & 32 \\
\hline BAI03 & $\begin{array}{c}\text { Mengelola, } \\
\text { Mengindetifikasi } \\
\text { dan Pembuatan } \\
\text { Solusi } \\
\end{array}$ & 5 & 15 & 2 & 14 & 1 & 2 & 3 & 6 & 37 \\
\hline BAI04 & $\begin{array}{c}\text { Mengelola } \\
\text { Ketersediaan } \\
\text { dan Kapasitas } \\
\end{array}$ & 9 & 27 & 4 & 12 & 3 & 6 & 3 & 6 & 51 \\
\hline BAI06 & $\begin{array}{l}\text { Mengelola } \\
\text { Perubahan }\end{array}$ & 5 & 15 & 4 & 12 & 1 & 2 & 3 & 6 & 35 \\
\hline BAI09 & Mengelola Asset & 5 & 15 & 5 & 5 & 3 & 6 & 3 & 6 & 32 \\
\hline BAI010 & $\begin{array}{l}\text { Mengelola } \\
\text { Konfigurasi }\end{array}$ & 9 & 27 & 4 & 12 & 3 & 6 & 3 & 6 & 51 \\
\hline
\end{tabular}

maju kedepannya. Berikut merupakan rangkuman hasil analisis kesenjangan.

Tabel 2. Hasil Analisis Kesenjangan Tingkat Kapabilitas

\begin{tabular}{|c|c|c|c|c|}
\hline No & Nama Proses & $\begin{array}{c}\text { Level } \\
\text { Kapabilitas } \\
\text { (a) }\end{array}$ & $\begin{array}{c}\text { Tager } \\
\text { Kapabilitas } \\
\text { (b) }\end{array}$ & $\begin{array}{c}\text { Nilai } \\
\text { Kesenjangan } \\
(\mathrm{b}-\mathrm{a})\end{array}$ \\
\hline 1 & $\begin{array}{ll}\text { APO07 } & \\
\text { Mengelola } & \\
\text { Sumber } & \text { Daya } \\
\text { Manusia } & \end{array}$ & 1 & 4 & 3 \\
\hline 2 & $\begin{array}{l}\text { BAI01 Mengelola } \\
\text { Program dan } \\
\text { Proyek }\end{array}$ & 0 & 5 & 5 \\
\hline 3 & $\begin{array}{l}\text { BAI02 Mengelola } \\
\text { Definisi } \\
\text { Persyaratan }\end{array}$ & 1 & 2 & 1 \\
\hline 4 & $\begin{array}{l}\text { BAI03 } \\
\text { Mengelola, } \\
\text { Mengindentifikasi } \\
\text { dan Pembuatan } \\
\text { Solusi }\end{array}$ & 1 & 3 & 2 \\
\hline 5 & $\begin{array}{l}\text { BAI04 Mengelola } \\
\text { Ketersediaan dan } \\
\text { Kapasistas }\end{array}$ & 1 & 5 & 4 \\
\hline 6 & $\begin{array}{l}\text { BAI06 Mengelola } \\
\text { Perubahan }\end{array}$ & 0 & 4 & 4 \\
\hline 7 & $\begin{array}{l}\text { BAI09 Mengelola } \\
\text { Asset }\end{array}$ & 0 & 5 & 5 \\
\hline 8 & $\begin{array}{l}\text { BAI10 Mengelola } \\
\text { Konfigurasi }\end{array}$ & 1 & 5 & 4 \\
\hline
\end{tabular}

Hasil kesenjangan tingkat kapabilitas untuk kondisi yang terjadi saat ini dengan kondisi yang diinginkan digunakan untuk pemberlakuan pada masing-masing proses yang terukur serta menentukan prioritas untuk melakukan perbaikan. Penentuan prioritas dapat dilakukan pada proses yang memiliki peran yang sangat penting untuk mencapai tujuan organisasi dan focus kepada proses yang memiliki gap pada tingkat kapabilitas.

\section{Penentuan Prioritas}

Dalam menentukan prioritas, hal pertama yang dilakukan adalah menentukan kriteria penialaian prioritas. Kriteria berhasil didapatkan berdasarkan hasil diskusi dengan Kepala Badan Pengembangan Teknologi Informasi (BPTI). Kriteria ini ditentukan berdasarkan hal apa sajakah yang harus dilihat pada pelaksanaan perbaikan ini. Dimana kriterianya dinilai berdasarkan dampak diterapkannya proses tersebut, kemudahan dalam implementasi yang dilihat dari GAP yang dimiliki masing-masing proses, dan kemudahan dan kesiapan organisasi yang dilihat dari segi SDM dan Teknologinya. Berikut hasil dari penentuan kriteria dari prosesproses yang ada seperti terlihat pada tabel 3. Berdasarkan hasil perhitungan matriks, dilihat dari 8 proses yang memiliki jumlah nilai prioritas 
paling besar yaitu sebesar 54 adalah proses APO07 Mengelola Sumber Daya Manusia dari sisi layanan di BPTI proses tersebut dapat mengganggu berjalannya proses pelayanan apabila tidak dipenuhi dengan baik.

\section{Rekomendasi Perbaikan}

Rekomendasi perbaikan yang diberikan didasarkan pada urutan suatu prioritas proses yang nantinya akan dilaksanakan yang didapat dari tabel prioritas perbaikan proses. Rekomendasi perbaikan diberikan berdasarkan Base Practice COBIT 5: Process Assesment Model.

\section{Kesimpulan}

Berdasarkan hasil penelitian dapat ditarik kesimpulan terkait Tata Kelola TI di Badan Pengembangan Teknologi Informasi (BPTI) yaitu:

1. Kerangka kerja COBIT 5 diambil dari beberapa proses area yang lebih relevan dengan tujuan untuk meningkatkan layanan TI di BPTI. Proses yang diambil diantaranya adalah APO07, BAI01, BAI02, BAI03, BAI04, BAI06, BAI09, dan BAI010.

2. Sesuai dengan rangkuman hasil pengukuran kapabilitas proses-proses COBIT 5 yang dinilai, tingkat kapabilitas proses di BPTI untuk kondisi saat ini sebagian besar masih berada pada level 1 dan sebagian kecil berada pada level 0 .

3. Prioritas perbaikan tingkat kapabilitas proses pada penelitian ini berdasarkan dampak dari penerapan, kemudahan dalam implementasi dan kesiapan dari organisasi baik dari segi SDM maupun dari segi teknologi. Proses yang memiliki prioritas utama untuk dilakukan perbaikan tingkat kapabilitas adalah proses APO07 yaitu Mengelola Sumber Daya Manusia karena kurangnya sumber daya manusia saat ini memberikan dampak terhadap perubahan yang akan dilakukan oleh TI serta memberikan dampak dalam pelayanan TI di BPTI.

\section{Daftar Pustaka}

Al-Abode, S. S. (2006). Information Systems Audit and Control Association (ISACA). A New Approach for Assessing the Maturity of Information system.
Ardima, M. B., Gernowo, R., \& Slamet, V. G. (2020). Pengukuran Tingkat Kapabilitas Sistem Tata Kelola TI Menggunakan Cobit 5 dengan ISO 38500. Jurnal Teknologi Informasi dan Ilmu Komputer (JTIIK), 7(3).

Cobit, S. (2012). A business framework for the governance and management of enterprise IT. Rolling Meadows.

Dauwango, S., \& Olii, S. (2019). Tingkat kapabilitas tata kelola teknologi informasi pada domain evaluate, direct, and montoring. Jambura Journal of informatics, 1(1), 19-26.

Dewantara, Amhar Davi. (2015). Pengukuran Tingkat Kapabilitas Tata Kelola Teknologi Informasi Berdasarkan COBIT 5: Studi Kasus Pusat Data dan Informasi (PUSDATIN) Arsip Nasional Republik Indonesia (ANRI). Jakarta: Universitas Indonesia

Fajarwati, S., Sarmini, S., \& Septiana, Y. (2018). Evaluasi Tata Kelola Teknologi Informasi Menggunakan Kerangka Kerja COBIT 5. JUITA: Jurnal Informatika, 6(2), 73-80.

Information Systems Audit and Control Association (ISACA). (2013). Cobit 5 Selfassessment Guide: Using Cobit 5. Isaca.

Jogiyanto, H. M. (2017). Sistem Tatakelola Teknologi Informasi. Yogyakarta: Penerbit ANDI.

Putri, R. E. (2016). Penilaian Kapabilitas Proses Tata Kelola TI Berdasarkan Proses DSS01 Pada Framework COBIT 5. Jurnal CoreIT: Jurnal Hasil Penelitian Ilmu Komputer dan Teknologi Informasi, 2(1), 41-54.

Rhamadani, Mega Wahyu. (2019). Pengukuran Tingkat Kapabilitas Tata Kelola Teknologi Informasi dan Rekomendasi Perbaikan Berdasarkan Framework COBIT 5 Studi Kasus Lembaga Non Pemerintahan. Jakarta: Universitas Gunadarma. 